\title{
Implementation of Multicultural Values in Islamic Religious Education Based Media Animation Pictures as Prevention of Religious Radicalism in Poso, Central Sulawesi, Indonesia
}

\author{
Hamlan Andi Baso Malla ${ }^{1, *}$, Misnah Misnah ${ }^{2}$ and A. Markarma ${ }^{1}$ \\ ${ }^{1}$ State Institute for Islamic Studies (IAIN), City of Palu, Indonesia \\ ${ }^{2}$ History Study Program, Tadulako University, City of Palu, Indonesia
}

\begin{abstract}
This study aims to promote multicultural values in the culture of Sintuwu Maroso the Poso community through the transformation of education which is integrated with Islamic religious subjects based on animated image media as prevention of radicalism in the school and community environment. Research methods is a qualitative descriptive study in the form of writing and oral words from people who are the object of research, in conducting research, researchers as the main instrument whose role is to observe observations of documents and conduct interviews with informants, analyze data, interpret data and interpret data compiled a report on tracking the value of local wisdom on the multicultural value of Sintuwu Maroso in the Poso community. Islamic religious education learning that is integrated between Islamic religious material and cultural material of the Poso Sintuwu Maroso community can produce students who are always obedient to their God, behave well with others and are far from understanding religion and radical religious behavior in multicultural / change communities. student characters. Islamic religious education learning that is integrated between Islamic religious material and cultural material of the Poso Sintuwu Maroso community can produce students who are always obedient to their God, behave well with others and are far from understanding religion and radical religious behavior in multicultural / change communities. student characters
\end{abstract}

Keywords: Multicultural Values, Islamic Religious, Media Animation, Prevention Radicalism.

\section{INTRODUCTION}

Multiculturalism is an essential problem faced by society in the current era of globalization. Multiculturalism is taken as a distinction in terms of culture, born of variations between fellow human beings, and from nationalities that have a diversity that's anxious regarding the present period of time era (Bae, 2020; Dadang Supardan, 2016). Indonesia is a country that has a multicultural ethnicity, religion, race, and culture that are interpreted as potential social forces to build a civil society or civil society (Joebagio \& Akhyar, 2019; Ratu et al., 2019). However, on the other hand, it can also give rise to social friction due to the depletion of local social values that are the social capital of the community. Multiculturalism is a necessity in people's lives that can give meaning to the meaning of differences so that they can avoid radicalism as understood by some people. Radicalism often results from a weak understanding of multicultural values in society and disrupts national stability that threatens national integration (Nayak, 2009; Yampolsky \& Amiot, 2016)

The reality of a multicultural, multi-ethnic, and multireligious Indonesian nation is a very wide range with radicalism which can lead to divisions and

${ }^{*}$ Address correspondence to this author at the State Institute for Islamic Studies (IAIN), City of Palu, Indonesia; Tel: +685256696169;

Fax: +451 460949; E-mail: hamlan@iainpalu.ac.id disintegration such as conflicts that occur in various regions in Indonesia. Responding to the reality of conflict in the community that occurred in Poso District, Central Sulawesi Province in 1999-2001, horizontal conflicts between Muslims and Christians and in 2004 continued with acts of terrorism and radicalism committed by Santoso terrorist group known as the commander of East Indonesian jihad committed acts of terror against civil society and the police and military to date. The conflict has always been a national issue in the print and electronic media reporting at the local and national level (https://news.detik.com, 2019).

Based on social facts faced by the people in Poso District, it is necessary to prevent social conflicts, especially on the influence of radicalism on behalf of religion. The solution offered during this analysis is to push philosophical system values supported native knowledge Sintuwu Maroso that is employed as a locution of mutual respect for cultural differences, serving to one another to assist among fellow voters through the motto of brotherhood, unity, and unity of the Poso community. Therefore, it is important to change the educational paradigm through the implementation of learning in Islamic religious education subjects in one school in Poso District, namely SMA Negeri 4 Poso (Public High School), the selection of this school is motivated by high multicultural values and this school has transformed Islamic learning from a literal normative understanding 
of Islam towards nuances of inclusive, tolerant and moderate Islamic insights, with the design of the implementation of multicultural values in Islamic religious learning based on animated media images through learning multicultural material as an effort to develop tolerant values in preventing the influence of religious radicalism on the personal learners at SMA Negeri 4 Poso.

This study aims to promote multicultural values in the culture of Sintuwu Maroso the Poso community through the transformation of education which is integrated with Islamic religious subjects based on animated image media as prevention of radicalism in the school and community environment.

\section{METHODS}

Research methods is a qualitative descriptive study in the form of writing and oral words from people who are the object of research, in conducting research, researchers as the main instrument whose role is to observe observations of documents and conduct interviews with informants, analyze data, interpret data and interpret data compiled a report on tracking the value of local wisdom on the multicultural value of Sintuwu Maroso in the Poso community. Qualitative data analysis techniques use Matthew B. Miles and A. Michael Huberman, namely data reduction, data presentation, data verification, and conclusion drawing techniques.

Data reduction is the process of selecting, focusing, simplifying, abstracting, the transformation of rough data arising from written records in the field that takes place continuously, the presentation of data is the result of the data that has been reduced to be discussed through the arrangement and described in sentence form according to the theme and classification on the subject matter to be arranged systematically and structured. Verification of data and concluding processes to ensure that the data is really valid and accurate.

Qualitative research on multicultural values in the Poso community will be continued with Classroom Action Research (Taggart \& Kemis, 2001). Thus to implement multicultural values in the teaching of Islamic religious education in Poso State High School 4 with research subjects are grade XI students, and Islamic religious education teachers, using the media of image animation as an effort to prevent radicalism in Poso.

\section{RESULTS \& DISCUSSIONS}

Based on the results of research conducted in Poso, data obtained that horizontal conflicts in Poso society that occurred in 1999-2001 were conflicts of different religions and ethnicities in Poso caused by low individual awareness and institutions for the importance of local cultural values and religious contexts that teach the values of brotherhood, unity, and tolerance in a multicultural society. The form of diversity in Poso is in the community activities of mutual respect among ethnic groups, namely Bare'e, Pamona, Kaili, Manado, Java, Bugis, Toraja, and other tribes mixed into one in the art of ancestral heritage in the past called dance Dero.

Dance Dero is a form of cultural preservation that has survived to this day in community activities, namely: 1). Thanksgiving ceremony activities will be abundant agricultural products that provide welfare for the people of Poso called Padungku. The Activity has a manifestation of customer behavior to maintain the values of tolerance, openness, mutual respect, mutual assistance in traditional padungku ceremonial activities. In the traditional ceremonial activity, the community prepares facilities and infrastructure both morally and materially for the success of the harvest event which will be coupled with traditional Dero dance. Padungku traditional ceremonies and traditional Dero dances as a form of glue of family relationships without looking at social status, religion, gender, youth, religious leaders, traditional leaders, mingled into one in the form of a circle accompanied by traditional music, chanting poems that are prerequisite with meaning kinship among fellow Poso people, as a form of gratitude to God Almighty for the abundant harvest (Ika, 2019; Lukman S. Tahir, 2019; Yulce Pansiang, 2019). Poso as a former conflict area in Central Sulawesi continues to make improvements and awareness of the importance of the value of brotherhood, unity, and tolerance through the philosophy of the Poso community called Sintuwu Maroso because historically the Poso community is a multicultural society and is open to accepting immigrant communities of different religions, cultures, languages, gender. The multicultural Poso is based on life philosophy Sintuwu Maroso nature of as a cultural heritage in the past in maintaining the integration of a safe, peaceful and peaceful region (Aat, 2019). Maintaining the integration of safe, peaceful and peaceful areas, one of them through the Dero dance regional culture as a multicultural manifestation of a tolerant and open Poso community is very important to 
create a safe and peaceful life so that it can become a resolution to post-conflict radicalism and terrorism in Poso. The promotion of cultural values by using a multicultural approach can create changes in society in the political world, social life, and education world. 2). The Dance performance was Dero also held at the ceremony to welcome honored guests, for example, regional leaders who visited Poso as a symbol of respect, respect for others who were considered to be beneficial to the people of Poso (Misnah, 2017; PaulBinyamin \& Haj-Yehia, 2019). The guest greeting ceremony which is respected by the people of Poso is a form of ancestral heritage in respecting others (Yan, 2018).

The Poso people have the local cultural values of Sintuwu Maroso and the culture is continuously transformed for the younger generation to prevent conflicts in the community. Sintuwu Maroso cultural values are important for the life of the Poso people after the conflict because they can change the paradigm of thinking and behave for the young generation of school age. The process of transforming multicultural values in the culture of the people in Poso can be done on learning in schools. In this context, Islamic spiritual education is one in all the topics that encompasses a terribly strategic role to inherit doctrine values that are extracted from the culture of a society that's designed within the medium of image animation. The design of animated media images about culture in Islamic religious education learning aims to provide a full understanding for students about the integration of multicultural cultural material and Islamic religious education learning is carried out as prevention of religious radicalism for students. The multicultural values of the culture Sintuwu Maroso in the Poso community will be described in the following.

Research data in the field shows that the Poso community conflict in 1999-2001 has implications for the emergence of understandings of radical ideology because of acts of revenge for victims when the conflict occurred in Poso. Acts of revenge based on violence during conflicts between Muslims and non-Muslims in the name of religion by using religious symbols are inseparable links. The issue of religion and conflict is a very extreme issue when linked to the issue of peace in Pos. Thus, qualitative research study data on multicultural values in Poso, namely the local wisdom of the Poso community in Sintuwu Maroso, will be a breakthrough in learning innovations in education, especially in Islamic religious education (PAI) subjects designed through image animation media that can provide behavioural changes. in students specifically tolerance, mutual respect, fellow feeling and openness among fellow students at school and society.

The research is an innovation in Islamic religious education learning in developing integrated learning resources between religion, culture, and learning technology. The integration can prepare students to face and master science and technology (science and technology), also has a moderate and tolerant religious insight that is prepared to respond to the current of globalization to produce humans who have good character (Asefi et al., 2019; Kurt et al., 2020; Sabic-ElRayess, 2020). Through learning Islamic religious education can provide knowledge, attitudes, and skills in responding to local and global challenges, especially in shaping the human character of responsibility, honesty, tolerant harmony, peace between the people and between religious communities in community life.

The individuals of the Poso Rule are one of the districts in Central Sulawesi Territory that have a culture of Sintuwu Maroso. One of Sintuwu Maroso culture is through Dero traditional dance which has values multicultural as ancestral heritage. In the traditional Dero dance, has the values of unity, unity, unity, diversity becomes a way of life residents of Poso

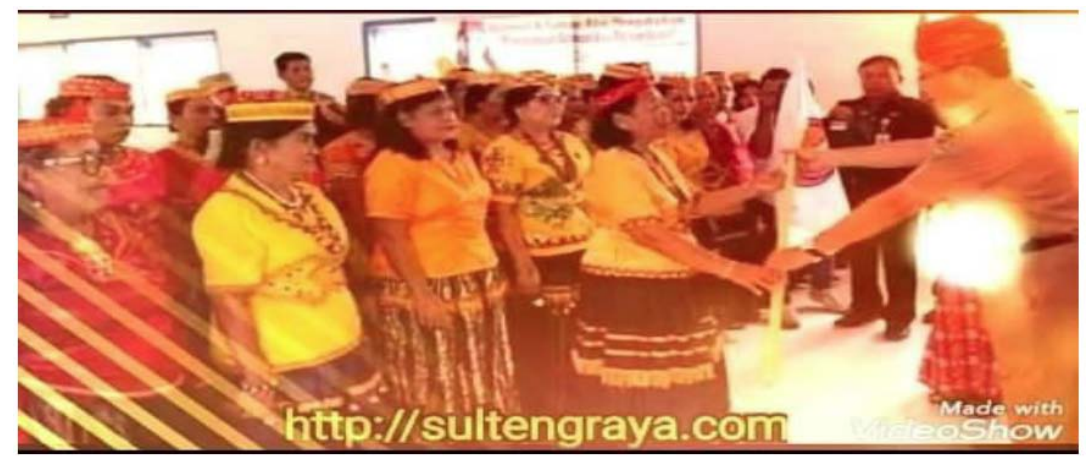

Figure 1: The multicultural value of Sintuwu Maroso as prevention of radicalism in Poso. 
until now survive in society Poso in maintaining the harmonious social environment. Local culture in society has historical values and has the concept of sustainability which is useful for life (Misnah et al., 2018; Nana Supriatna, 2016; Supriatna, 2019). As an effort to sustain local culture, the Poso community will be integrated with the learning of Islamic education to introduce local cultural values to students so that they realize the importance of those values that are internalized in school and community life. The cultural values of Sintiwu Maroso are integrated into Islamic religious subjects designed in the medium of animated images as an innovation in the transformation of learning in education, especially Islamic religious education subjects in Poso Regency.

The teacher as a facilitator has the main role to produce learning innovations by designing animated picture media about multicultural cultural values material in the Poso community. In the animation, media images will be integrated with material about the creed, worship, morals with values multicultural in Sintuwu Maroso culture which is implemented in the learning process. This is done as an effort to prevent radicalism in the school environment and society. Based on the results of observations and interviews conducted with teachers of Islamic religious subjects in schools concluded a data finding that the teacher has not integrated the values of Sintuwu Maroso Multicultural culture in the learning process of Islamic religious education. Besides, there is the view of some people that religion teaches about symbols of violence during the Poso conflict (Yulce Pansiang, 2019). Based on these problems, this research was conducted as a learning innovation in the context of the transformation of integrated Islamic religious education subjects as a form of promotion of the excellence of cultural values inherited from ancestral heritage in everyday life. This research is a collaboration between researchers and Islamic religious education teachers as an activity to develop regional culture-based material on Islamic religious education subjects in SMA 4 Poso as an effort to develop religious and social values of students so that students can implement religious teachings that are tolerant, mutual respect, respect each other, please help and not question cultural, ethnic and religious differences in people's lives.

The implementation of Islamic religious education learning that is integrated with multicultural values is based on the standard curricula of the 2013 curriculum which emphasizes the spiritual dimension in core competency 1 , a social dimension incompetency 2 , core competency 3 dimensions of knowledge and core competency 4 , namely the dimension of skills in each meeting. Core standards (KI) 1-4, basic competencies $(K D)$, and indicators do not yet reflect the dimensions of multicultural education materials integrated into Islamic religious education learning materials. Therefore, this study was conducted to examine multicultural material in the culture of Sintuwu Maroso based on instructional media designed in the preparation of syllabi and lesson plans. The preparation of the syllabus and RPP of Islamic religious education aims to provide students with a full understanding of the importance of the social dimension in maintaining unity, unity, tolerance, brotherhood among people who have different religious and cultural beliefs in the Poso community.

SMA Negeri 4 Poso which is located in Poso City with multicultural patterns of students, balanced between Muslims and Christians, has a religious tribe, Bare'e tribe, Pamona tribe, Kaili tribe, Javanese tribe, Bugis tribe, Tator tribe, and other tribes are schools that continue to maintain the brotherhood, unity, and tolerance of fellow school residents. The sociological and anthropological conditions of multicultural learners can easily lead to conflict if not managed properly. Moreover, the condition of understudies will

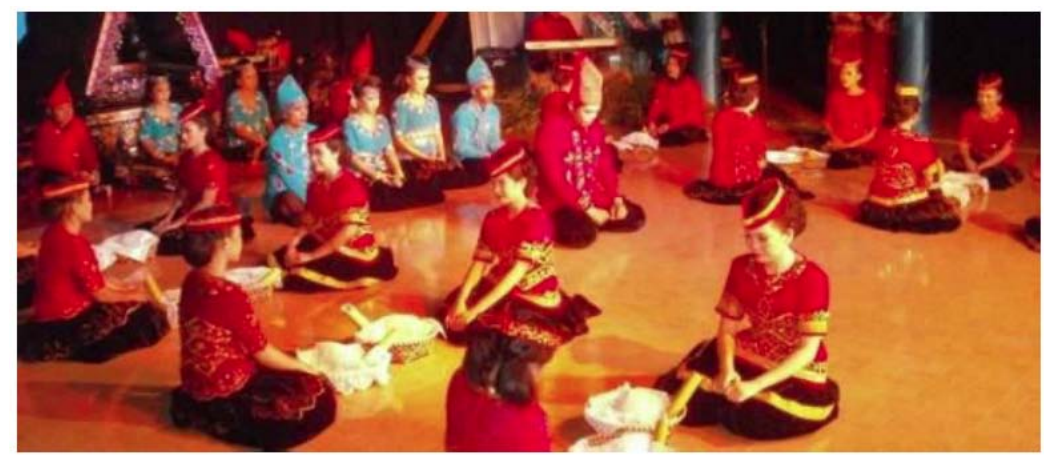

Figure 2: Picture of multicultural values in culture Sintuwu Maroso thanks giving for agriculture (padungku). 


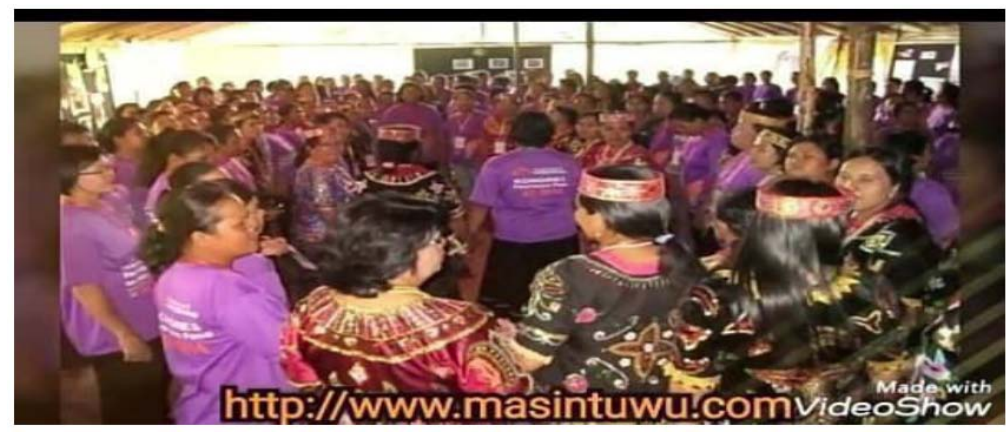

Figure 3: Traditional dero dance for welcoming guests.

continuously be kept up integration and solidarity in case overseen legitimately within the learning prepare. The implementation of cultural values was Sintuwu Maroso designed in the medium of image animation compiled jointly by researchers and partner teachers, while the description of the meeting was explained as follows inactivities action research.

The description of the display of the implementation of animation media is carried out between cycle 1 and cycle 2 as follows.

\section{Implementation of Cycle Actions 1}

Following the scenario that has been prepared, the first meeting is held on Friday the first lesson at 07.3009.30 WITA. The initial activity of the teacher prepares a subject matter with topics about the creed, the value of God, worship, and disciplined honesty, caring, tolerance, and peace. The first cycle was carried out using the group discussion method which was divided into 3 groups with 3 material topics. Group 1 discusses Aqedah (divinity), Group 2 discusses worship) and group 3 discusses morals (honest, disciplined, tolerant, and peaceful behavior). Students in Islamic religious education courses are equipped with knowledge about the concepts of Aqedah, worship, and morals. In the learning process takes place students are given the knowledge of the basics of religion based on values multicultural. Next, the teacher distributes worksheets to each student containing 4 problem descriptions with the same problem for each group, the teacher then explains how to work on the worksheet This time is given with a duration of 25 minutes to work on a group worksheet. Each group was allowed to present the results of group work discussions and was guided by Islamic religious education teachers in class.

At the end of the learning process in the class, the teacher gives the students time to conclude the material that was discussed in cycle 1 , then the teacher continues by giving a written test to measure students' understanding of the topic related to the first cycle, thus in the process of learning activities of the participants students do not understand the basics of Islam that are associated with multicultural values following the local wisdom of the Poso community, students experience obstacles, namely how to connect the basic material of the Islamic religion with the multicultural values of the Poso community. the results obtained in cycle 1 students do not understand the material of faith, morals associated with multicultural based on Sintuwu Maroso, based on the results obtained cognitive, affective and psychomotor competence of students in cycle 1 is not optimal with the evaluation value that the students get a score of knowledge values with values 64 (enough) attitude 60 (enough) and 61 (enough). Based on the results of the cycle 1 activities, the learning outcomes have not been completed so it will be continued in the second cycle. Before proceeding to cycle 2 , the teacher assigns the task to students to look for multicultural values in the Poso community based on culture Sintuwu Maroso.

\section{Implementation of Cycle Actions II}

The second cycle was held on Monday starting at 07.30-09.30 pm, the teaching material at the second cycle meeting was multicultural values based on Sintuwu Maroso local culture in the community. The initial activity of the teacher preparing learning media, namely multicultural cultural values in the Poso community, began with the presentation of an animated video display of multicultural values Sintuwu Maroso in the traditional art activity Dero which is a cultural heritage as a motto for the Poso community to maintain unity, unity, togetherness, and ownership. an open attitude in maintaining the integrity of the Poso region. Then students are asked to record values that have benefits from the activity of showing the video. For the second meeting, the use of instructional media is based on image animation by connecting the regional 
culture in Poso through the YouTube display, which was prepared using the inquiry learning model with a method group investigation. Then the teacher continues to prepare the group discussion activities by distributing each worksheet containing 4 questions, then the teacher allows all groups to present the findings of each group. In this activity, the teacher becomes a facilitator giving explanations to strengthen the descriptions of group explanations that were already described in front of the class. Students succeeded in identifying multicultural values in Islamic religious lessons in culture Sintuwu Maroso which are described in the results of the discussion activities investigation group, these values are tolerance, openness, empathy, and sympathetic values.

These values are by the concept of the Poso community's motto to maintain unity, unity, and togetherness to produce a peaceful society. Implementation of the multicultural value of Sintuwu Maroso culture in the Poso community through image animation media on Islamic religious education lessons. In the second cycle of research, these students were declared successful with several indicators of achievement, namely: 1) students were able to understand multicultural values in culture Sintuwu Maroso as prevention of radicalism in Poso, 2). The pattern of life tolerant, openness, empathy, sympathetic as a form of culture of Sintuwu Maroso related to the habits of students respecting each other during worship activities for Muslims in conducting prayer and for students who are Muslim in terms of respect when carrying out worship and students behave empathically giving assistance to friends when in the learning process, for example, lending a pencil, a pen when classmates do not have stationery in the learning process activities and do not see differences, religion, and ethnicity.

Islamic religious education learning results in meaningful learning that students are not only equipped with knowledge about the multicultural concept of culture Sintuwu Maroso but are equipped with positive attitudes, concrete actions, and beneficial for them in the school environment and Public. The results of student evaluations at the end of learning activities with cognitive values 83 , affective 80 , and psychomotor 88. Multicultural integration in Islamic religious education learning through image animation media according to systematic steps taken by schools to produce students as generations those who understand differences in the community are not disputed, let alone trigger sources of conflict, but differences multicultural as a means for social integration to create a peaceful atmosphere in social life at school and in the community, maintain fraternity, unity, tolerance and be honest according to culture The Poso Sintuwu Maroso community is based on the teachings of Islam with the structure of the teachings of aqidah, shari'ah and morals. Through learning activities of Islamic religious education based on animated media images provide learning to students to understand the teachings of Islam and local culture well, change the way of thinking and behaving of students who have a spirit of brotherhood, unity, tolerance, and honesty. This way of thinking and behaving can prevent students from understanding a radical religion.

\section{CONCLUSION}

Islamic religious education learning that is integrated between Islamic religious material and cultural material of the Poso Sintuwu Maroso community can produce students who are always obedient to their God, behave well with others, and are far from understanding religion and radical religious behavior in multicultural / change communities. student characters. An integrated model of Islamic religious education learning based on image, animation media can develop the personality of students who are tolerant, inclusive based on the spirit of brotherhood, unity, and honesty values by the values of Islamic teachings and the cultural value of Sintuwu Maroso, a humanist Poso community. The innovation of Islamic religious education learning in implementing values multicultural in the culture Sintuwu Maroso results in the competence of religious, humanistic, knowledge, and skills to successfully prevent students from being influenced by religious radicalism.

\section{REFERENCES}

Aat. (2019). Interview: Mantan Narapidada Terorisme, Tokoh Pemuda.

Asefi, M., Khasraghi, S. S., \& Roders, A. P. (2019). Art and technology interactions in Islamic and Christian context: Historical approach to architectural globalization. Frontiers of Architectural Research, 8(1), 66-79. https://doi.org/10.1016/j.foar.2018.12.003

Bae, S. M. (2020). The relationship between social capital acculturative stress and depressive symptoms in multicultura adolescents: Verification using multivariate latent growth modeling. International Journal of Intercultural Relations, 74(November 2019), 127-135. https://doi.org/10.1016/j.ijintrel.2019.11.007

Dadang Supardan. (2016). Manusia, Kekerasan, Multikultural, dan Transformasi Pendidikan. Rizqi Press.

Https://news.detik.com. (2019). Radikalisme-agama-telah-menyebardi-aparatur-negara-mengapa-bisa-terjadi. 
Ibnu Hadjar. (2002). Dasar-Dasar Metodologi Penelitian Kualitatif dan Kuantitatif, . RajaGrafindo Persada.

Ika. (2019). Interview: Perwakilan akademisi Mengenai Bentuk Keberagaman Masyarakat Poso.

Joebagio, H., \& Akhyar, M. (2019). Peace Education As The Development Of Social Skill In Social Science Learning. 29(2).

Kurt, Y., Sinkovics, N., Sinkovics, R. R., \& Yamin, M. (2020). The role of spirituality in Islamic business networks: The case of internationalizing Turkish SMEs. Journal of World Business, 55(1), 101034. https://doi.org/10.1016/j.jwb.2019.101034

Lukman S. Tahir. (2019). Interview: Tokoh Akademisi Peneliti Pengiat Terorisme Di poso.

Miles, M. B., \& Huberman, A. M. (1992). Qualitative Data Analysis: An Expanded Sourcebook, 2nd edn, Thousand Oaks. (Sage Publications, Ed.).

Milles, M. B., \& Hubarman, A. M. (n.d.). Analisis Data Kualitatif ,(Jakarta; UI Press), 15-16.diterjemahkan oleh Tjecep Rohendi, .

Misnah. (2017). Pengembangan Pembelajaran Berbasis Kearifan Lokal Etnik Kaili Dalam Nosarara Nosabatutu Di Sulawesi Tengan Sebagai Proses Pembelajaran Sejarah lokal Di SMA Di Kabupaten Sigi Sulawesi Tengah. Universitas Pendidikan Indonesia. Bandung.

Misnah, M., Supriatna, N., Sjamsuddin, H., Ali, M., \& Ratu, B. (2018). Preserving Culture Wisdom of Nosialampale by Means Ethno Pedagogical Approach in Teaching of History. Advanced Science Letters, 24(11), 8236-8238. https://doi.org/10.1166/asl.2018.12531

Nana Supriatna. (2016). Ecopedagogy Membangun Kecerdasan Ekologis Dalam Pembelajaran Sejarah (Cetakan Pe). Remaja Rosdakarya.
Nayak, A. (2009). Racism and Antiracism. In International Encyclopedia of Human Geography (Second Edi, Vol. 11). Elsevier. https://doi.org/10.1016/B978-008044910-4.00993-7

Paul-Binyamin, I., \& Haj-Yehia, K. (2019). Multicultural education in teacher education: Shared experience and awareness of power relations as a prerequisite for conflictual identities dialogue in Israel. Teaching and Teacher Education, 85, 249-259.

https://doi.org/10.1016/j.tate.2019.06.021

Ratu, B., Misnah, \& Amirulah. (2019). Peace Education Based On Local Wisdom Nosarara Nosabatutu. Jurnal, 106-118. https://doi.org/10.17509/jomsign.v3i2.20958

Sabic-El-Rayess, A. (2020). Epistemological shifts in knowledge and education in Islam: A new perspective on the emergence of radicalization amongst Muslims. International Journal of Educational Development, 73(December 2019), 102148. https://doi.org/10.1016/j.ijedudev.2019.102148

Supriatna, N. (2019). Social Studies Learning To Build Students To Compete in Era 4.0. Presented in the Seminar and Workshop of the Social Sciences Education Master's Curriculum, March 27, 2019.

Taggart, \& Kemis. (2001). Taggart. And K. (2001). The Action research Planner. Deakin University, Victoria, Australia.

Yampolsky, M. A., \& Amiot, C. E. (2016). Discrimination and multicultural identity configurations: The mediating role of stress. International Journal of Intercultural Relations, 55, 86-96. https://doi.org/10.1016/j.ijintrel.2016.09.002

Yan. (2018). Interview; Menjaga Hubungan Kekeluargaaan Melalui Budaya Adat Poso.

Yulce Pansiang. (2019). Interview: Implementasi Multiklutur masyarakat Poso pasca Konflik.

Received on 02-12-2020

Accepted on 27-12-2020

Published on 18-01-2021

DOI: https://doi.org/10.6000/1929-4409.2021.10.08

(c) 2021 Malla et al.; Licensee Lifescience Global.

This is an open access article licensed under the terms of the Creative Commons Attribution Non-Commercial License (http://creativecommons.org/licenses/by-nc/3.0/) which permits unrestricted, non-commercial use, distribution and reproduction in any medium, provided the work is properly cited. 